\title{
Favorable climatic regime for maintaining the present-day geometry of the Gregoriev Glacier, Inner Tien Shan
}

\author{
K. Fujita ${ }^{1}$, N. Takeuchi ${ }^{2}$, S. A. Nikitin ${ }^{3}$, A. B. Surazakov ${ }^{4}$, S. Okamoto ${ }^{1}$, V. B. Aizen ${ }^{4}$, and J. Kubota ${ }^{5}$ \\ ${ }^{1}$ Graduate School of Environmental Studies, Nagoya University, Nagoya, Japan \\ ${ }^{2}$ Graduate School of Science, Chiba University, Chiba, Japan \\ ${ }^{3}$ Department of Glacio-Climatology, Tomsk State University, Tomsk, Russia \\ ${ }^{4}$ College of Science, University of Idaho, Moscow, Idaho, USA \\ ${ }^{5}$ Research Institute for Humanity and Nature, Kyoto, Japan
}

Received: 9 February 2011 - Published in The Cryosphere Discuss.: 14 March 2011

Revised: 29 June 2011 - Accepted: 1 July 2011 - Published: 11 July 2011

\begin{abstract}
We conducted 2 yr (2005-2007) of in situ meteorological and glaciological observations on the Gregoriev Glacier, a flat-top glacier within the Inner Tien Shan, Kyrgyzstan. Relative carrier-phase GPS surveys reveal a vertical lowering at the summit of the glacier. Based on snow density data and an energy-mass balance model, we estimate that the annual precipitation and summer mean temperature required to maintain the glacier in the current state are $289 \mathrm{~mm}$ and $-3.8{ }^{\circ} \mathrm{C}$ at the glacier summit $(4600 \mathrm{~m}$ a.s.l.), respectively. The good agreement between dynamically derived precipitation and the long-term observed precipitation at a nearby station in the Tien Shan $(296 \mathrm{~mm}$ at $3614 \mathrm{~m}$ a.s.l. for the period 1930-2002) suggests that the glacier has been in a near steady-state in terms of mass supply. The glacier massbalance, reconstructed based on meteorological data from the Tien Shan station for the past $80 \mathrm{yr}$, explains the observed fluctuations in glacier extent, particularly the negative mass balance in the 1990s.
\end{abstract}

\section{Introduction}

Glaciers are one of the most sensitive indicators of climate change (Lemke et al., 2007). The evaluation of changes in glacier area and volume has many applications in hydrological modelling and estimations of variability in water resources. Despite the extremely dry climate in central Asia, the Tien Shan holds one of the greatest concentrations of

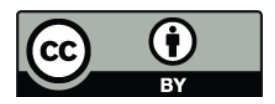

Correspondence to: K. Fujita (cozy@nagoya-u.jp) glacier ice in the mid-latitudes, representing a vital source of water for more than 100 million people living in the region.

Glacier dynamics are determined primarily by climatemediated glacier mass-balance (the net gain or loss of snow and ice). Despite the importance of knowledge on glacier mass-balance variability in terms of regional water resources, regular measurements of glacier mass-balance and other ground-based glaciological data were discontinued in the Tien Shan due to collapse of Soviet Union in 1991. To overcome this lack of data, the extent of glaciers in this region has been studied using remote sensing data (e.g. Khromova et al., 2003; Aizen et al., 2006, 2007b; Narama et al., 2006; Surazakov and Aizen, 2006; Bolch, 2007; Kutuzov and Shahgedanova, 2009). However, information on glacier variability derived from remote sensing data, which also includes aerial photographs taken in the mid-20th century, is not sufficient to understand the nature of glacier dynamics and its climatic forcing. Long-term observations of climate and glacier mass-balance at several representative glaciers in the Tien Shan were started in 1960 and continued until 1991 (e.g. Golubev, 1976; Konovalov, 1979; Suslov, 1980; Krenke, 1982; Aizen et al., 1983; Aizen, 1985; Avsuyk, 1984; Glazirin, 1991), but few mass-balance studies have been undertaken in the past $20 \mathrm{yr}$. Reconstructions of glacier mass balance, using a mass balance model, are a valid approach to understanding the behaviour of glaciers in the Tien Shan, because long-term climate data are available for the region; however, there have been few studies of this type (Hagg et al., 2005). To reconstruct the mass balance of the Tien Shan glaciers and to understand their threshold for the present-day glacier geometory, we analysed the main climatic variables (precipitation and summer air temperature)

Published by Copernicus Publications on behalf of the European Geosciences Union. 
observed at the Tien Shan meteorological station, performed in situ meteorological and mass-balance observations at the summit of the Gregoriev Glacier for 2 yr (2005-2007), and considered the results of an energy-mass balance model.

\section{Study site, observations, and methods}

\subsection{Location}

The Gregoriev Glacier is an ice-cap type (flat-summit) glacier on the south slope of the Terskey-Alatoo Range in the Inner Tien Shan, Kyrgyzstan ( $41^{\circ} 58^{\prime} \mathrm{N}, 77^{\circ} 55^{\prime} \mathrm{E}$; Fig. 1). The long-term (1930-2002) annual means of air temperature and precipitation at the Tien Shan station $\left(41^{\circ} 55^{\prime} \mathrm{N}\right.$, $78^{\circ} 14^{\prime} \mathrm{E}$; $3614 \mathrm{~m}$ above sea level (a.s.1.) and located $27 \mathrm{~km}$ from the Gregoriev Glacier) are $-7.7^{\circ} \mathrm{C}$ and $296 \mathrm{~mm}$, respectively. This glacier has been well investigated because of easy access provided by a nearby highway (e.g. Thompson et al., 1993; Nagornov et al., 2006). Changes in air temperature at the glacier summit during the middle of the 20th century have been retrieved from stable water isotopes in ice cores drilled in 1990 and from changes in borehole temperature (Thompson et al., 1993). Although the thermodynamic state of the glacier has been depicted by a two-dimensional flow-line model, the mass balance as a boundary condition was estimated by a simplified relation based on temperature, precipitation, and altitude (Nagornov et al., 2006).

Figure 1 shows a satellite image of the glacier taken on 21 August 1980. The area-altitude distribution of the glacier, which is used to calculate the area-averaged mass balance (specific mass balance; hereafter, SMB), is obtained from recent Landsat ETM+ images (captured in 1999 and 2006) that show the glacier extent, and from an SRTM digital elevation model (February 2000; Jarvis et al., 2008) and ASTERGDEM (average of 2000-2008; ASTER-GDEM, 2009) for the 50-m altitude band. Temporal change in glacier area is not taken into account in the present analysis.

\subsection{Observations}

We conducted in situ observations of the Gregoriev Glacier for $2 \mathrm{yr}$ between July 2005 and September 2007, including meteorological observations using an automatic weather station (AWS), surveys using a relative carrier-phase Global Positioning System (hereafter, GPS), and conventional massbalance measurements using wooden stakes and snow-pits. A surface-to-bedrock ice core ( $87.46 \mathrm{~m}$ deep) was drilled in September 2007. The ice-core is currently being processed and examined for multi-proxy analysis.

An AWS was installed at the summit of the glacier on 12 July 2005, recording air temperature, relative humidity, wind speed and direction, and downward and upward solar radiation at 30-min intervals. Changes in surface level were measured by two different instruments: ultra-sonic and

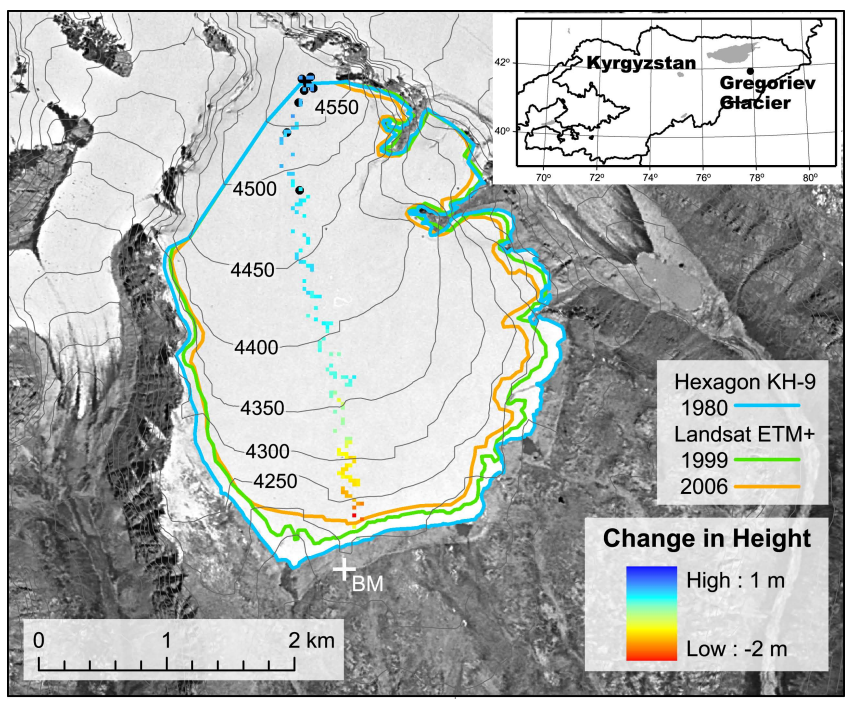

Fig. 1. Location (inset) and satellite image of the Gregoriev Glacier taken by Hexagon KH-9 on 21 August 1980 (Surazakov and Aizen, 2010). Glacier boundaries are manually delineated from satellite images of Hexagon KH-9 (1980) and pan-sharpened Landsat ETM+ (1999 and 2006). Contour lines (50-m interval) are drawn based on an SRTM-DEM (February 2000). The white cross and black dots denote the benchmark for GPS surveys and mass balance stakes, respectively. Coloured 15-m cells denote changes in elevation, which were averaged from 1-m resolution DEMs obtained by GPS surveys in July 2006 and August 2007 (see the text for details).

photo-diode sensors. Precipitation was measured by a tipping bucket installed near the terminus (near the GPS benchmark; BM in Fig. 1). The precipitation gauge was filled with antifreeze to avoid water evaporation from the collected snowfalls. Precipitation was only measured for 5 months (August-December 2006) due to battery failure. All variables were compiled to daily values.

Six stakes were installed around the summit of the glacier on 27 August 2006 for mass balance measurements and surveys of surface flow velocity. We also measured the mass balance and location of one pre-existing stake found during the 2006 survey. Changes in stake heights and AWS data were used to calculate the mass balance between 2006 and 2007. A snow-pit (2-3 m deep) was dug during each visit to the glacier. The stratigraphy and depths of dust layers were recorded along the pit wall, and a density profile was obtained. Snow density data are necessary to convert changes in stake height to water equivalent (w.e.). The depths of dust layers are used to validate the energy-mass balance model.

Static surveys by single frequency GPS receivers were performed to measure stake positions on the glacier in each year. One GPS receiver was installed as a base station at a benchmark near the glacier terminus (white cross in Fig. 1). Only the position of the AWS was surveyed in 2005. The locations of stakes were surveyed in 2006 and 2007, yielding the flow velocities. 
Kinematic surveys, using the same receivers as those described above, were performed on the glacier in 2006 and 2007. Post-processing of GPS data was performed using Waypoint GrafNav/GrafNet software (version 6.03a) to obtain the relative positions and altitudes of all points on a common Universal Transverse Mercator projection (UTM, zone $43 \mathrm{~N}$, WGS-84 reference system). Data were excluded from subsequent analyses if the software output error (formal error) was worse than $1 \mathrm{~m}$ (in both location and altitude). The average formal error of kinematic surveys was $0.18 \mathrm{~m}$ in location and $0.21 \mathrm{~m}$ in altitude. The measurement errors obtained using the same instrument have previously been reported as $0.1-0.4 \mathrm{~m}$ in location and $0.2-0.9 \mathrm{~m}$ in altitude, based on repeated measurements of several benchmarks in the Bhutan and Nepal Himalayas (Fujita et al., 2008, 2009).

All the surveyed points (10023 in 2006 and 12954 in 2007) were converted to 1-m-resolution digital elevation models (DEMs) by the inverse distance weighting method, whereby the measured points used to obtain the altitude of a grid cell are limited to within the targeted grid cell. Grid cells without a measurement point were excluded from subsequent analyses. Ultimately, we considered 6363 cells for 2006 and 9796 cells for 2007.

\subsection{Energy-mass balance model}

The energy-mass balance model used in this study calculates the daily heat balance at the glacier surface, including the radiation balance, sensible and latent turbulent heat fluxes, heat conduction into the glacier, and mass balance consisting of snow accumulation, melt, refreezing, and evaporation, as follows (Fujita and Ageta, 2000; Fujita et al., 2007):

$$
\begin{aligned}
\max \left[Q_{\mathrm{M}} ; 0\right] & =(1-\alpha) R_{\mathrm{S}}+R_{\mathrm{L}}-\min \left[\sigma T_{\mathrm{S}}^{4} ; 315.6\right] \\
& +Q_{\mathrm{S}}+E_{\mathrm{V}} l_{\mathrm{e}}+Q_{\mathrm{G}}
\end{aligned}
$$

Heat for melting $\left(Q_{\mathrm{M}}\right)$ is obtained if the right-hand side of the equation is greater than zero. Absorbed short-wave radiation is calculated from the surface albedo $(\alpha)$ and downward short-wave radiation $\left(R_{\mathrm{S}}\right)$. Downward long-wave radiation $\left(R_{\mathrm{L}}\right)$ is calculated from the air temperature, relative humidity, and the ratio of downward short-wave radiation to that at the top of the atmosphere, using an empirical scheme (Fujita and Ageta, 2000). Upward long-wave radiation is obtained from the Stefan-Boltzmann constant $(\sigma)$ and the surface temperature in Kelvin $\left(T_{\mathrm{S}}\right)$, assuming a black body for the snow/ice surface. A melting surface $\left(0^{\circ} \mathrm{C}\right.$ surface temperature) releases upward long-wave radiation of $315.6\left(\mathrm{~W} \mathrm{~m}^{-2}\right)$. Sensible $\left(Q_{\mathrm{S}}\right)$ and latent $\left(E_{\mathrm{V}} l_{\mathrm{e}}\right)$ turbulent heat fluxes are obtained by bulk methods. The latent heat for evaporation of water or ice $\left(l_{\mathrm{e}}\right)$ is determined from the surface temperature. Conductive heat into the glacier ice $\left(Q_{\mathrm{G}}\right)$ is obtained by calculating the temperature profile of the snow layer and/or glacier ice. The surface temperature is obtained to satisfy all heat balance equations by iterative calculation of conductive heat.
The conductive heat is obtained by calculating temperature profile from the surface to depth of $20 \mathrm{~m}$ at $0.5 \mathrm{~m}$ interval. All heat components are positive when fluxes are directed toward the surface. Mass balance $(B)$ at any location on the glacier is calculated as follows:

$B=C a-Q_{\mathrm{M}} / l_{\mathrm{m}}+E_{\mathrm{V}}+R_{\mathrm{F}}$

Solid precipitation ( $\mathrm{Ca}$, positive sign), which is determined along with air temperature, is equivalent to accumulation over the glacier. Mass is removed from the glacier as meltwater $\left(Q_{\mathrm{M}} / l_{\mathrm{m}}\right.$, positive sign) and evaporation $\left(E_{\mathrm{V}}\right.$, negative sign). $l_{\mathrm{m}}$ is the latent heat for melting ice. Some of the meltwater is fixed to the glacier by refreezing ( $R_{\mathrm{F}}$, positive sign) if the glacier ice is cold enough (Fujita et al., 1996). The refreezing amount is calculated in the model by considering the conduction of heat into glacier ice and the presence of water at the interface between the snow layer and glacier ice (Fujita and Ageta, 2000). Also considered is refreezing during winter and shorter cooling events by assuming the maximum water content as $5 \%$ in volume. Special attention is paid to the treatment of the surface albedo $(\alpha)$ because it varies enormously in space and time, even for a single glacier (the albedo declines down a glacier and during the course of the melt season). The albedo in the model is calculated by a simplified concept of multiple scattering in the ice plate whose thickness related with the surface snow density. The surface snow density changes with snow compaction. The albedo of bare ice was set to 0.19 , as observed in 2006. Detailed schemes for the entire model have been described by Fujita and Ageta (2000) and Fujita et al. (2007), and the albedo and snow densification schemes have been described by $\mathrm{Fu}-$ jita (2007).

\subsection{Long-term data}

To reconstruct the long-term mass balance, it is necessary to prepare a set of daily meteorological variables, such as air temperature, precipitation, solar radiation, relative humidity, and wind speed. Monthly air temperature and precipitation data recorded at the Tien Shan station are used for the period 1930-2002. Because gridded pentad (5-day average) precipitation is available from 1979, we generated daily air temperature and precipitation for the period 1979-2002, as follows:

$$
\begin{aligned}
& T_{z, \text { day }}=T_{\text {ncep, day }}-T_{\mathrm{ncep}, \text { mon }}+T_{\mathrm{ts}, \text { mon }}-\Gamma_{\text {day }}(z-3614) \\
& P_{\text {day }}=\frac{P_{\text {gpcp,day }}}{P_{\text {gpcp, mon }}} P_{\mathrm{ts}, \text { mon }}
\end{aligned}
$$

where $T$ and $P$ denote air temperature and precipitation, respectively; $T_{z \text {, day }}$ is the daily air temperature at a given altitude $(z)$; and the subscripts "ncep", "gpcp", "day", "mon," and "ts" denote NCEP/NCAR reanalysis data (Kalnay et al., 1996), GPCP precipitation data (Adler et al., 2003), daily and monthly values, and data from the Tien Shan station, respectively. The lapse rate of air temperature $\left(\Gamma_{\text {day }}\right.$, 
expressed as an absolute value) is estimated from geopotential heights and air temperatures at 500 and $600 \mathrm{hPa}$, from the NCEP/NCAR reanalysis dataset. Because data at the Tien Shan station are unavailable after 2003, we use the relations between reanalysis datasets and data from the Tien Shan station averaged for each month, for the period 1979-2002 ( $\left(-T_{\mathrm{ncep}, \mathrm{mon}}+T_{\mathrm{ts}, \mathrm{mon}}\right)_{1979-2002}$ for air temperature and $\left(P_{\mathrm{ts}, \mathrm{mon}} / P_{\mathrm{gpcp}, \mathrm{mon}}\right)_{1979-2002}$ for precipitation). Daily values of solar radiation, relative humidity, and wind speed are modified for the glacier (see below for details) for the period 1979-2007. For the period 1930-1978, we estimated the daily air temperature and precipitation in the same manner as the Eq. (3), but iterative calculations were performed mentioned below.

\subsection{Setting of different seasonal cycles}

To estimate the conditions of favorable climatic regimes and perform calculations for the period prior to which reanalysis datasets are available, we used 29 seasonal cycles (19792007) of reanalysis datasets because the seasonality of meteorological variables has a marked effect on the mass balance (Fujita, 2008). We estimate daily precipitation $\left(P_{\text {day,yr }}\right)$ during a given year (yr) as follows:

$P_{\text {day }, \mathrm{yr}}=\frac{P_{\mathrm{gpcp}, \mathrm{day}, \mathrm{yr}}}{\sum_{\mathrm{day}=1}^{365} P_{\mathrm{gpcp}, \mathrm{day}, \mathrm{yr}}} P_{\mathrm{ann}}$

where $P_{\text {gpcp,day,yr }}$ is the GPCP daily precipitation during a given year. A seasonal cycle can be set by Eq. (4) for a given annual precipitation $\left(P_{\mathrm{ann}}\right)$. To obtain a favorable temperature condition under a given annual precipitation, for example, we vary air temperature by $0.1{ }^{\circ} \mathrm{C}$ steps and then determine the favorable air temperature and mass balance profile when SMB is zero. We finally obtain the average and standard deviation of the favorable summer mean air temperature (average of June-August, JJA) at the summit of the glacier (4600 m a.s.l.) and the equilibrium line altitude (ELA) that yield the zero SMB. The other daily variables (solar radiation, relative humidity, and wind speed) were used without any modification.

\section{Results and discussion}

\subsection{Observed and gap-filled meteorological data}

Because the AWS records were occasionally interrupted due to battery problems, we estimated missing data by linear regression equations established between observed data and the modified reanalysis datasets mentioned above. Table 1 summarizes the parameters used in the regression equations and the correlation coefficients. A marked seasonality yields high correlation coefficients for air temperature and solar radiation. Although wind speed and relative humidity show weaker or insignificant correlations, these variables are less
Table 1. Parameters for estimating daily meteorological variables $(y)$ at the summit of the Gregoriev Glacier by linear regression $(y=a x+b)$ from variables of reanalysis datasets $(x)$. Air temperature and precipitation are preliminarily modified for the Tien Shan station (see Sect. 2.4). Also listed is the correlation coefficient $(r)$ and its significance level $(p)$. Regression equations for wind speed and precipitation are obtained by assuming a zero intercept $(b=0)$ to avoid negative wind speed and persistent precipitation.

\begin{tabular}{lrrrl}
\hline Variable & $a$ & $b$ & $r$ & $p<$ \\
\hline Air temperature & 0.93 & -1.61 & 0.916 & 0.001 \\
Wind speed & 1.37 & 0.00 & 0.047 & - \\
Relative humidity & -0.18 & 79.33 & -0.158 & 0.01 \\
Solar radiation & 0.91 & 42.99 & 0.812 & 0.001 \\
Precipitation & 1.18 & 0.00 & 0.614 & 0.01 \\
\hline
\end{tabular}

important in calculating the heat balance because of low air pressure at high elevations (Fujita and Ageta, 2000). Pentad precipitation shows a significant correlation between point observations and gridded data. We finally established daily variables for the 2-yr observation period, from July 2005 to September 2007 (Fig. 2). These variables were used as input for validation calculations.

\subsection{Flow field and net balance required to maintain the glacier in its current state}

Repeated surveys enabled calculation of the flow velocity at the summit of the Gregoriev Glacier (Fig. 3 and Table 2). The lowest stake (i.e. the pre-existing stake) was found during the 2006 survey and was presumably installed during a previous campaign. The locations of the AWS and Stake 3 show small amounts of horizontal movement ( $\mathrm{dH}$ in Table 2), thereby guaranteeing undisturbed climatic signals in ice cores from this site. Vertical changes in the surface elevation (dSF in Table 2) are slightly positive for the period 2006-2007. When the surface net balance is considered (dSA in Table 2), however, a given fixed point for each stake shows a marked lowering (dVD in Table 2). This vertical lowering reflects vertical downward flow throughout the glacier and the slope along the flow line. If horizontal movements are sufficiently small (e.g. AWS and Stake 3), vertical lowering represents the net balance required to maintain the present-day glacier geometry. In addition, the AWS was situated 1.3-2.4 m higher than the surrounding stakes (Stakes 1-4). The surface inclination from the AWS toward the other stakes was sufficiently small $\left(-41\right.$ to $\left.-23 \mathrm{~mm} \mathrm{~m}^{-1}\right)$ that the downward surface movement along the flow line was negligible. We obtained an averaged vertical lowering of $0.53 \pm 0.01 \mathrm{~m} \mathrm{yr}^{-1}$ from the AWS site. The average surface snow density was $451 \pm 46 \mathrm{~kg} \mathrm{~m}^{-3}$ (calculated from three snow-pits dug each survey); thus, the net accumulation was $238 \pm 27 \mathrm{~mm}$ w.e. $\mathrm{yr}^{-1}$ (Table 3). The precipitation amount required to maintain the present-day 


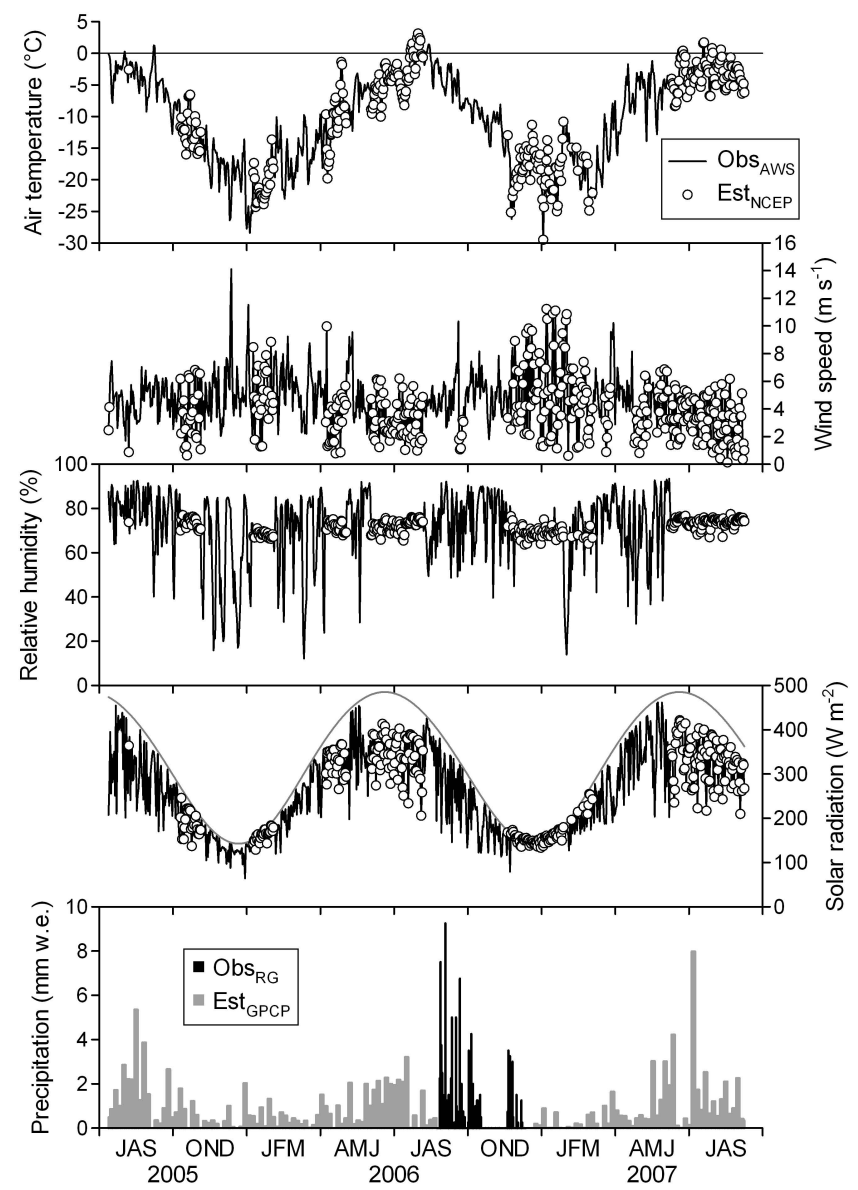

Fig. 2. Meteorological records observed at the summit of the Gregoriev Glacier from July 2005 to September 2007. The upper to lower panels respectively show daily values of air temperature, wind speed, relative humidity, solar radiation, and precipitation. Lines and circles in the panels (except precipitation) indicate observed and estimated variables, respectively. In the lowermost panel (precipitation), black and grey bars represent observed and estimated daily precipitation, respectively. The grey line in the panel showing solar radiation represents the solar irradiance calculated for the top of the atmosphere.

glacier geometry can be determined if we know the mass loss by evaporation, which is obtained by model calculations (see Sect. 3.5).

\subsection{Changes in elevation of the glacier surface}

We calculated changes in the surface elevation of the glacier by comparing the 1-m DEMs constructed in 2006 and 2007 (Figs. 1 and 4a). The elevation difference was calculated at a point for which elevation data were available for both years. The elevation changes calculated at 1-m resolution are averaged to $15-\mathrm{m}$ resolution to assist visual assessment (Fig. 1) and are shown for the 50-m altitude band (Fig. 4a). The elevation changes show a reasonable altitudinal profile, except

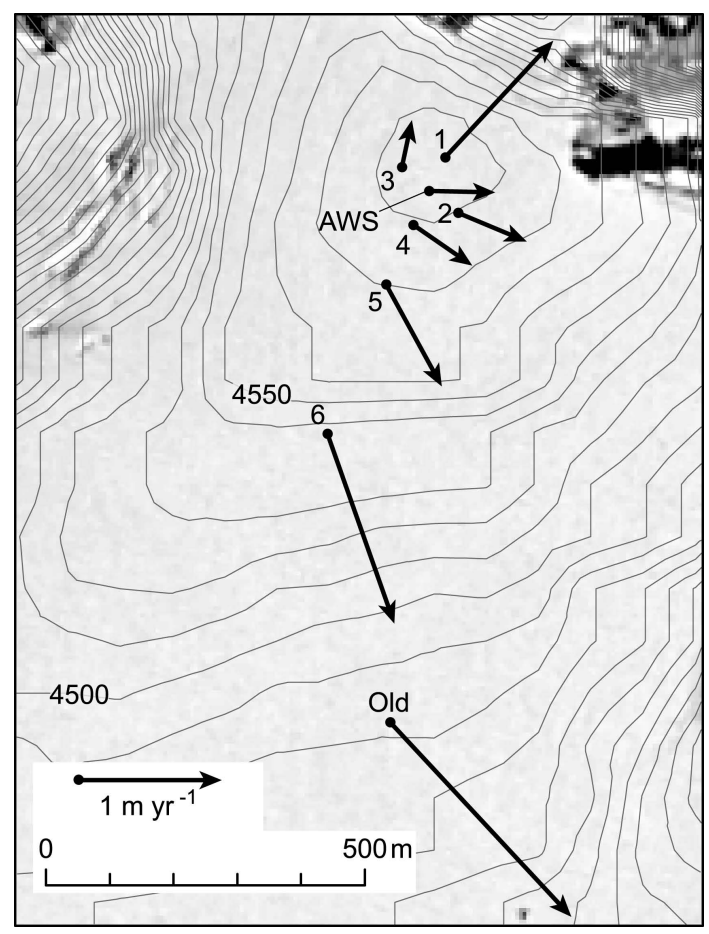

Fig. 3. Surface flow velocities (arrows) measured at stakes (dots) on the Gregoriev Glacier between 2006 and 2007. Contour lines (10-m interval) are drawn based on an SRTM-DEM. The background image is a Hexagon KH-9 image taken on 21 August 1980. Values are summarized in Table 2. AWS, Old and other numbers denote automatic weather station, pre-existing stake and stakes we installed, respectively.

Table 2. Flow components and change in height of stakes around the summit of the Gregoriev Glacier for 2006 and 2007 (except AWS, which was also measured in 2005). dH, dSF, dSA and $\mathrm{dVD}$ denote changes in the horizontal position of the stake, vertical change in the glacier surface, snow accumulation obtained from the stake height, and vertical lowering by glacier flow, respectively. The horizontal flow directions are shown in Fig. 3.

\begin{tabular}{lcrcc}
\hline Stake & $\begin{array}{c}\mathrm{dH} \\
\left(\mathrm{m} \mathrm{yr}^{-1}\right)\end{array}$ & $\begin{array}{r}\mathrm{dSF} \\
(\mathrm{m})\end{array}$ & $\begin{array}{c}\mathrm{dSA} \\
(\mathrm{m})\end{array}$ & $\begin{array}{c}\mathrm{dVD} \\
\left(\mathrm{m} \mathrm{yr}^{-1}\right)\end{array}$ \\
\hline AWS 2005/2006 & 0.20 & -0.25 & 0.33 & -0.52 \\
AWS 2006/2007 & 0.60 & 0.25 & 0.79 & -0.53 \\
Stake 1 & 1.12 & 0.29 & 1.53 & -1.21 \\
Stake 2 & 0.46 & 0.28 & 1.21 & -0.91 \\
Stake 3 & 0.25 & 0.39 & 0.96 & -0.56 \\
Stake 4 & 0.44 & 0.27 & 1.18 & -0.89 \\
Stake 5 & 0.79 & 0.16 & 1.26 & -1.07 \\
Stake 6 & 1.45 & -0.07 & 1.15 & -1.19 \\
Old stake & 1.96 & -0.09 & 0.35 & -0.43 \\
\hline
\end{tabular}



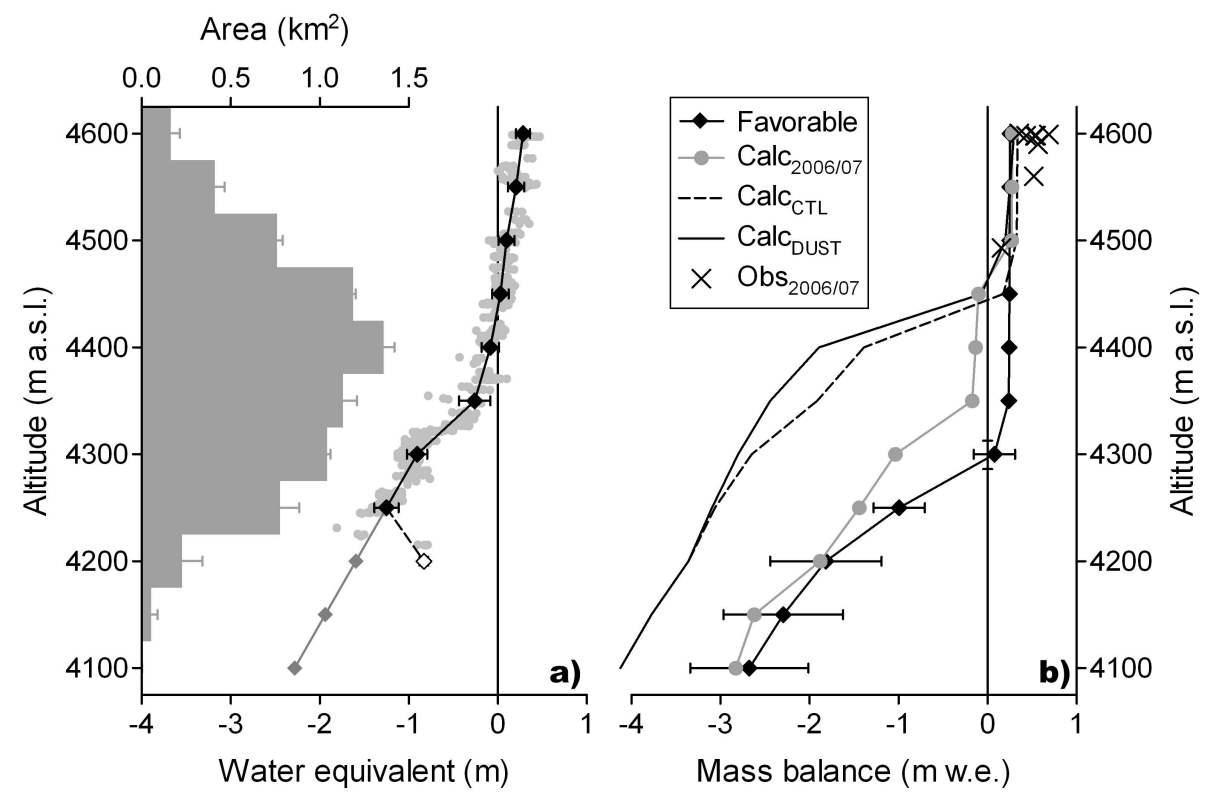

Fig. 4. (a) Altitudinal distributions of area and changes in surface elevation for the Gregoriev Glacier between July 2006 and August 2007. (b) Mass balance profiles calculated for the period 2005-2007 and favorable profile for the present-day glacier geometry. The area data with error bars in (a) are obtained from SRTM and ASTER-GDEM, with the glacier extent delineated from Landsat ETM+ images taken in 1999 and 2006. Grey dots, and black and grey diamonds along the solid line in (a) denote changes in a 1-m grid cell, averages at the 50-m altitude band, and extrapolated changes for the unmeasured lower part of the glacier, respectively. The lowest survey point (open diamond) was excluded from the analysis because it probably detected the bedrock. Black diamonds with error bars, grey circles, and solid and broken lines in (b) denote the favorable mass balance profile for a zero specific mass balance, profile for the period 2006-2007, and profiles for the period 2005-2006, for which the albedo reduction is considered (solid line) or not considered (broken line), respectively. Crosses in (b) denote the mass balance calculated from changes in stake height and from the average snow density.

Table 3. Annual net accumulation, precipitation and summer mean (JJA) temperature required to maintain the present-day geometry of the Gregoriev Glacier. The snow density was measured from three snow pits excavated every year. Evaporation is the average of the model calculation for $29 \mathrm{yr}$. Equilibrium line altitude (ELA) yielding zero specific mass balance is also shown.

\begin{tabular}{|c|c|}
\hline Vertical lowering by glacier flow & $0.53 \pm 0.01 \mathrm{~m} \mathrm{yr}^{-1}$ \\
\hline Surface snow density & $451 \pm 46 \mathrm{~kg} \mathrm{~m}^{-3}$ \\
\hline Net accumulation & $238 \pm 27$ mm w.e. $\mathrm{yr}^{-1}$ \\
\hline Modelled evaporation & $51 \pm 8 \mathrm{~mm}$ w.e. $\mathrm{yr}^{-1}$ \\
\hline Dynamically derived precipitation & $289 \pm 35 \mathrm{~mm} \mathrm{yr}^{-1}$ \\
\hline Precipitation at Tien Shan station & $296 \pm 73 \mathrm{~mm} \mathrm{yr}^{-1}$ \\
\hline $\begin{array}{l}\text { JJA temperature at the glacier } \\
\text { summit ( } 4600 \mathrm{~m} \text { a.s.1.) }\end{array}$ & $-3.84 \pm 0.48^{\circ} \mathrm{C}$ \\
\hline ELA & $4299 \pm 13 \mathrm{~m}$ a.s.1. \\
\hline
\end{tabular}

for the lowermost part of the glacier, where bedrock is probably encountered. We extrapolated the elevation change at the lowermost part of the glacier using the data at 4300 and $4250 \mathrm{~m}$ a.s.1. The uncertainty due to extrapolation over the lowermost altitude is considered to be minor because the unmeasured area accounts for only $4 \%$ of the total glacier area.
Table 4. Specific mass balances (SMB) calculated for the Gregoriev Glacier.

\begin{tabular}{lcc}
\hline & $\begin{array}{c}\text { Duration } \\
\text { (days) }\end{array}$ & $\begin{array}{c}\text { SMB } \\
\text { (m w.e.) }\end{array}$ \\
\hline GPS survey 2006-2007 & 373 & -0.36 \\
Calculation 2006-2007 & 373 & -0.41 \\
Control calculation 2005-2006 & 407 & -1.34 \\
Dust-run 2005-2006 & 407 & -1.60 \\
\hline
\end{tabular}

Considering the area-altitude distribution (Fig. 4a), the SMB is $-0.36 \mathrm{~m}$ w.e. for the period 2006-2007 (Table 4).

\subsection{Validation of the energy-mass balance model and impact of dust events}

We performed mass balance calculations for the period 2005-2007 using the energy-mass balance model and the gap-filled meteorological data, as mentioned above. Figure 5 compares the calculated changes in albedo and relative surface height at the glacier summit with observed data. Although the modelled surface appears to follow the observed 


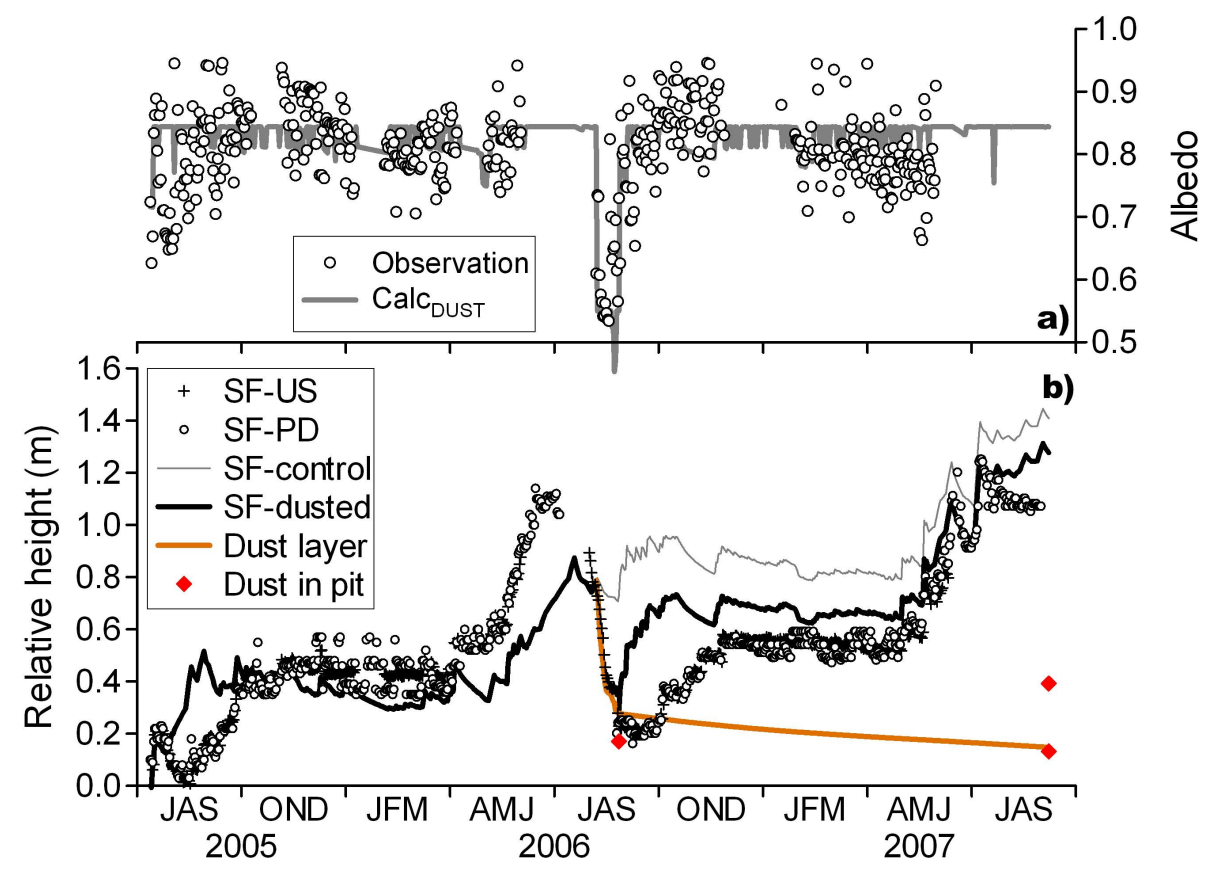

Fig. 5. Albedo (a) and relative surface height (b) at the summit of the Gregoriev Glacier from July 2005 to September 2007. Circles and the thick grey line in (a) denote observed and calculated albedos (dusted run). Symbols in (b) denote surface levels measured by an ultrasonic sensor (crosses, SF-US) and by a photo-diode sensor (circles, SF-PD). Lines in (b) denote calculated surface levels in the control run (thin grey line, SF-control), dust run (thick black line, SF-dusted), and the modelled dust layer tracked in the snow layer (thick brown line, Dust layer). The calculated surface levels overlap for the first year. Also shown are the dust layers observed in the snow pits excavated in 2006 and 2007 (red diamonds).

surface in the first year, a large depletion of the surface in August 2006 was not reproduced by the model, meaning that the inconsistency between observations and calculations increased in the second year (thin line in Fig. 5b). The observed surface albedo showed a large reduction when the surface was depleted in August 2006 (Fig. 5a). The presence of a dust layer at a depth of $0.065 \mathrm{~m}$ in the snow-pit excavated in August 2006 (red diamonds in Fig. 5b) indicates that a dust-fall event darkened the snow surface, causing a marked lowering of the surface due to melting. Therefore, we darkened the surface in the calculation using the dusttracking scheme established by Fujita (2007), in which the position of dust is traced by considering snow compaction. The albedo of a dusty surface is assumed to be 0.55 , based on observations (Fig. 5a). The dust run reproduces a reduction in albedo (Fig. 5a) and the consequent surface lowering (Fig. 5b), meaning that the change in surface level during the second year is consistent with that observed (thick black line in Fig. 5b), although some discrepancy remains in the autumn of 2006. A deeper dust layer observed in September 2007 supports the representativeness of the traced dust layer (red diamonds and thick brown line in Fig. 5b). Another dust layer observed in the shallower part of the snowpit in September 2007 would have formed during MarchApril 2007, as suggested by the stable surface position and lower albedo in the spring of 2007 . The calculated and ob-
Table 5. Observed and calculated mass balances (mmw.e.) at the summit of the Gregoriev Glacier for the two observational periods.

\begin{tabular}{ccc}
\hline & Observed & Calculated \\
\hline $2005-2006$ & 166 & 197 \\
$2006-2007$ & 325 & 276 \\
\hline
\end{tabular}

served mass balances at the summit for the two observational periods are consistent with each other (Table 5). The SMB $(-0.41 \mathrm{~m}$ w.e. $)$ of the calculation for the period 2006-2007 is consistent with the GPS surveys $(-0.36 \mathrm{~m}$ w.e., Table 4$)$.

Mass balance profiles obtained for the control and dust runs for the period 2005-2006 show a significant difference around the middle part of the glacier (4300-4400 ma.s.l.; Fig. 4b). Despite the significant surface lowering due to dust fall in the calculation (Fig. 5b), meltwater was refrozen within the cold snow pack around the glacier summit. At the lower part of the glacier, on the other hand, dust fall did not affect the mass balance because of the small amount of surface snow, even in the control run. Dust fall has a strong effect on the timing of appearance of an ice surface with a low albedo (0.19) on the surface, thereby affecting the mass balance around the middle part of the glacier. The dusted 
SMB $(-1.60 \mathrm{~m}$ w.e. $)$ was much more negative than that of the control run $(-1.34 \mathrm{~m}$ w.e.; Table 4$)$.

\subsection{Climate required to maintain the current state of the glacier}

Using the energy-mass balance model and the estimated meteorological variables (see above), evaporation at the summit of the glacier for the period 1979-2007 was calculated to be $51 \pm 8 \mathrm{~mm}$ w.e. $\mathrm{yr}^{-1}$ (Table 3). The calculation also showed that meltwater was refrozen in the snow, meaning that no discharge occurred from the summit during this period. Annual precipitation, which is equivalent to the sum of net balance and evaporation under a condition of no discharge, was $289 \pm 35 \mathrm{~mm} \mathrm{yr}^{-1}$, which is consistent with the long-term average recorded at the Tien Shan station $\left(296 \pm 73 \mathrm{~mm} \mathrm{yr}^{-1}\right.$ for the period 1930-2002) (Table 3).

If annual precipitation is constrained by the dynamically derived precipitation, the air temperatures required to maintain the present-day glacier geometry can be obtained from iterative calculations (see Sect. 2.5). The averages and standard deviations of JJA temperature at the summit and ELA are $-3.84 \pm 0.48^{\circ} \mathrm{C}$ and $4299 \pm 13 \mathrm{~m}$ a.s.l., respectively (Table 3). Variability in temperature is derived from variability in the dynamically derived precipitation $( \pm 35 \mathrm{~mm})$ and the 29 different seasonal cycles (1979-2007). Figures 4b and 6 show a favorable mass balance profile, and the JJA temperature and annual precipitation for the present-day glacier geometry, respectively.

Our analysis did not consider glacier dynamics. The altitude-area distribution of the glacier is assumed to have been constant during the analysis period, whereas shrinkage of the glacier has been reported based on remote sensing data (e.g. Aizen et al., 2006, 2007b; Narama et al., 2006; Kutuzov and Shahgedanova, 2009) (Fig. 1). An increase in the area of the lower part of the glacier would result in a reduced SMB, corresponding to a cooler favorable temperature condition for the present-day glacier geometry. If the lower area of the glacier (3900-4100 m a.s.l.) is assumed to be larger than the present-day area by $0.71 \mathrm{~km}^{2}(10 \%$ of the present-day total area), the favorable JJA temperature would be cooler by $0.18^{\circ} \mathrm{C}$, which is less than the uncertainty due to the seasonality of meteorological data $\left(0.48^{\circ} \mathrm{C}\right)$.

Many other climatic regimes could also be invoked to maintain the current geometry of the glacier. To describe the location of the dynamically derived precipitation and favorable JJA temperature, and the long-term observed data, we calculated the possible climatic regimes using the same approach as that described above (Sect. 2.5), whereby we varied the annual precipitation from 50 to $600 \mathrm{~mm}$ at steps of $50 \mathrm{~mm}$ and then sought the favorable temperature.

Figure 6 shows the possible climatic regimes for the current glacier geometry together with the dynamically derived and long-term observed regimes. The wetter climate generally requires the warmer condition to maintain the cur-

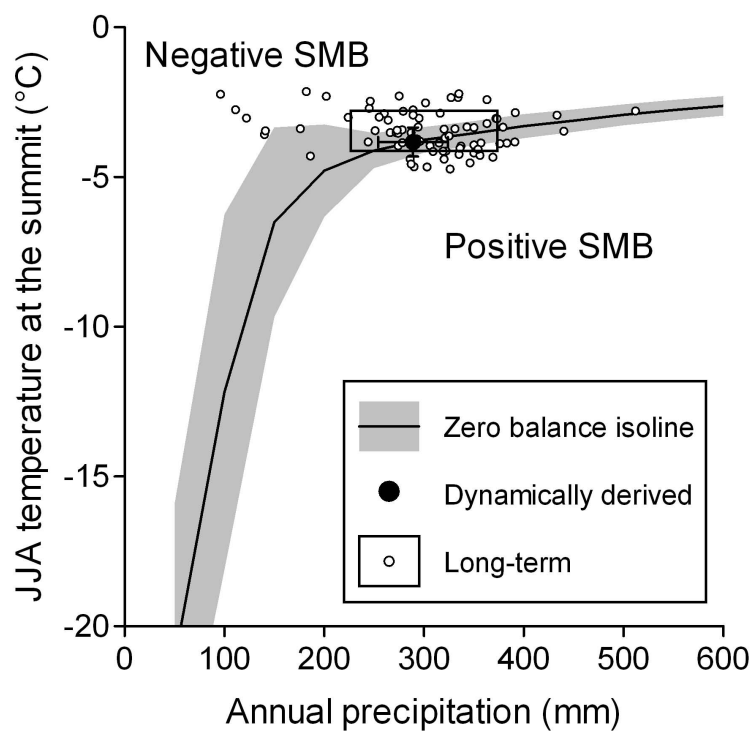

Fig. 6. Possible climatic regimes yielding zero specific mass balance (SMB) for the current geometry of the Gregoriev Glacier (line with shading) together with dynamically derived regime (solid circle) and long-term regimes estimated from data collected at the Tien Shan station (open circles). The rectangle denotes the range of longterm averages $( \pm 1 \sigma)$.

rent glacier geometry, as noted in previous studies (Oerlemans and Fortuin, 1992; Fujita, 2008). Under the extreme arid environment ( $<100 \mathrm{~mm}$ precipitation), ablation is caused mainly by evaporation (not melting), meaning that the glacier does not attain an SMB value of zero even under the very cold environment. The steep slope of the zero SMB isoline under the arid environment $(<200 \mathrm{~mm})$ suggests that the SMB is more sensitive to change in precipitation than to change in JJA temperature. Under the modest arid environment $(>200 \mathrm{~mm})$, in contrast, change in JJA temperature has a greater effect on SMB than does precipitation, as indicated by the gentle slope of the zero SMB isoline. The consistency between dynamically derived precipitation and the long-term observed precipitation suggests that the Gregoriev Glacier has been in a near steady-state in terms of mass supply. However, the long-term observed JJA temperature (open circles and box) is slightly warmer than the favorable JJA temperature (solid circle), suggesting that the recent retreat of the glacier has been driven mainly by warming rather than precipitation.

\subsection{Mass balance reconstruction}

We calculated the long-term mass balance for the past $80 \mathrm{yr}$ (Fig. 7). Because the precipitation record of the Tien Shan station showed a discrepancy with surrounding stations $(\mathrm{Ku}-$ tuzov and Shahgedanova, 2009), the calculated results using NCEP/NCAR and GPCP reanalysis datasets are also shown. The calculated SMB and ELA are consistent with 

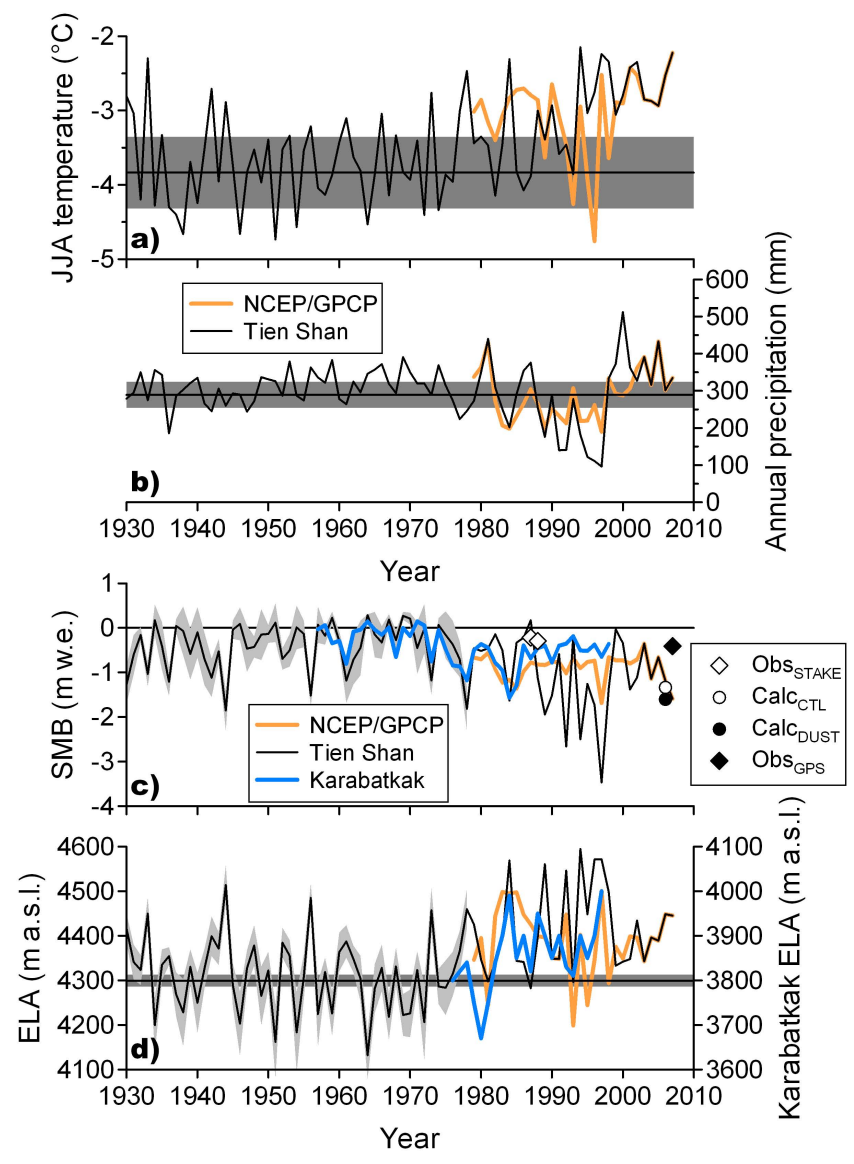

Fig. 7. (a) Summer (June-August, JJA) mean air temperature at $4600 \mathrm{~m}$ a.s.l., (b) annual precipitation, (c) calculated specific mass balance (SMB), and (d) calculated equilibrium line altitude (ELA) of the Gregoriev Glacier for the past $80 \mathrm{yr}$. Thick orange lines denote the gridded datasets. Thick blue lines denote records of the Karabatkak Glacier. Diamonds and circles in (c) denote the observed and calculated SMBs, respectively. Horizontal lines with dark grey bands denote the favorable variables for the present-day glacier geometry. Light grey shading for the SMB and ELA denotes the standard deviation obtained from different seasonal cycles of input.

observation data for the Karabatkak Glacier, located on the northern slopes of the same mountain range as that considered in the present study $\left(42^{\circ} 09^{\prime} \mathrm{N}, 78^{\circ} 16^{\prime} \mathrm{E} ; 35 \mathrm{~km}\right.$ from Gregoriev Glacier; data from Dyurgerov, 2002). The calculation results are also supported by observation data for the Gregoriev Glacier (open diamonds in Fig. 7c; data from Dyurgerov, 2002). The ELA of the Karabatkak Glacier appears to be $500 \mathrm{~m}$ lower than that of the Gregoriev Glacier (Fig. 7d), because the average accumulation at the former is about 2.5 times greater than that at the latter. However, fluctuations in SMB and ELA calculated for the Gregoriev Glacier are consistent with those for the Karabatkak Glacier, suggesting that the climatic variables which affect the glacier mass balance (i.e. precipitation and JJA temperature) show similar fluctuations throughout this region, whereas the baselines of annual precipitation differ between the two glaciers.

We also confirmed the influence of constant glacier area in the assumption on the resulting mass balance, in the same manner as that for the favorable JJA temperature (as described above). If we assume the lower area (3900$4100 \mathrm{~m}$ a.s.1.) to be larger than the present-day size by $0.71 \mathrm{~km}^{2}(10 \%$ of the present-day total area), the specific mass balance is more negative by $0.15 \mathrm{mw}$.e., which is the average for the calculation period, while the average uncertainty due to different seasonal cycles of meteorological inputs is $0.47 \mathrm{~m}$ w.e. This result indicates that a change in glacier extent has a smaller impact on the SMB than does uncertainty due to seasonal cycles (Fig. 7c).

The correlation coefficients between mass balance and single monthly mean air temperatures are worse than -0.675 (July). The strongest four correlations are obtained for the multi-monthly averages of JJA (-0.732), JA (July-August, -0.719), MJJAS (May-September, -0.718), and JJ (JuneJuly, -0.715). The correlation coefficients between mass balance and single monthly precipitation are worse than 0.498 (June); the strongest four correlations are obtained for annual data (0.678), MJJA (May-August, 0.672), MJJAS (0.671), and JJA (0.655). Therefore, we conclude that annual variability in the mass balance of the glacier has been strongly influenced by annual variability in JJA temperature and annual precipitation.

By comparing the JJA temperature, annual precipitation, ELA, and SMB with the favorable climatic regime $\left(-3.84^{\circ} \mathrm{C}\right.$ as JJA temperature at the glacier summit and $289 \mathrm{~mm}$ as annual precipitation), we can investigate which variables have controlled the glacier mass balance in each decade. Warm conditions that were occasionally observed before 1980 appear to be the main cause of negative mass balances. After 1980 , in contrast, a marked reduction in precipitation resulted in accelerated mass loss of the glacier for two decades. Despite a recovery in annual precipitation after the 1990s, warm temperatures (above those of the favorable condition) appear to have forced wasting of the ice mass of the glacier. Another calculated result using the gridded datasets (orange lines in Fig. 7) shows less negative SMB, being more consistent with the observed SMB during the 1990s because the GPCP dataset showed a smaller deficit in precipitation. Although the GPCP dataset should also include the Tien Shan station data, the precipitation deficit of the 1990s was moderated by the surrounding station data as well as satellite data. This discrepancy suggests that these station data must be used with care, although we currently have no data with which to validate them. Nevertheless, the present calculations provide great detail with respect to the behaviour of glacier mass balance over the past $80 \mathrm{yr}$, whereas Kutuzov and Shahgedanova (2009) reported accelerated shrinkage of glacier extent in this region based on remote sensing data and the climate records of the Tien Shan station. 


\section{Conclusions}

We calculated the favorable accumulation amount required to maintain the present-day geometry of the Gregoriev Glacier (a flat-top glacier in the Inner Tien Shan, Kyrgyzstan) based on relative carrier-phase GPS surveys that detected the vertical lowering rate of stakes at the glacier summit. We established linear relations between meteorological variables that were simultaneously observed at the glacier summit during 2005-2007, and gridded reanalysis datasets. Based on an energy-mass balance model and estimated meteorological inputs, we calculated the average evaporation for the period 1979-2007, thereby yielding the dynamically derived precipitation $\left(289 \pm 35 \mathrm{~mm} \mathrm{yr}^{-1}\right)$ for the present-day glacier geometry. The dynamically derived precipitation is consistent with the long-term average precipitation recorded at the nearby Tien Shan station $\left(296 \pm 73 \mathrm{~mm} \mathrm{yr}^{-1}\right)$, suggesting that the glacier has been in a near steady-state in terms of mass supply. Constrained by the dynamically derived precipitation, the favorable JJA mean temperature is $-3.84 \pm 0.48{ }^{\circ} \mathrm{C}$, as required to maintain the present-day glacier geometry. A reconstructed long-term mass balance, based on climate data from the Tien Shan station, reveals in detail the fluctuations in glacier mass balance over the past $80 \mathrm{yr}$. Our study fills decadal gaps between remotely sensed images that have been recently utilized to detect changes in glacier extent in the Tien Shan. Although glacier dynamics are not considered in the mass balance reconstruction, we confirmed that the effect of changing glacier extent on mass-balance and favorable conditions is insignificant compared with the calculated uncertainty due to the varying seasonality of meteorological inputs. In reality, glaciers are never in a steady state during a period of fluctuating climate. Nevertheless, we believe that it is meaningful to seek the favorable climatic regime, which serves as a reference in understanding fluctuations in glacier mass balance and the drivers of such fluctuations. This study provides the long-term annual mass balance for the past $80 \mathrm{yr}$, which are important data as boundary forcing for fluctuations in glacier geometry.

Model validation revealed that the influence on glacier mass balance of a darkened surface due to dust fall should be taken into account (Fig. 5). However, the dust effect is not considered in the long-term mass balance reconstruction. We are currently analysing ice cores retrieved from the summit of the Gregoriev Glacier in 2007. If a relation is established between the concentration of dust particles in the ice core and surface albedo, it will be possible to obtain a more realistic reconstruction of the glacier mass balance. For this calculation, the timing of dust fall has a strong effect on the mass balance (Fujita, 2007). This type of calculation represents an alternative application of the results of ice-core analyses.

If spatially interpolated or extrapolated meteorological inputs are prepared, it is possible to calculate spatial and temporal changes in glacier mass balance over a wider area, thereby filling decadal gaps in glacier fluctuations revealed by remote sensing data. Because the energy-mass balance model used in this study also outputs glacier runoff, it will be possible to analyse the regional water cycle (e.g. Aizen et al., 2007a; Hagg et al., 2007).

Acknowledgements. We are deeply indebted to B. Moldobekov and C. Reigber (Central Asian Institute for Applied Geosciences) and Top Asia Co. Ltd. (Kyrgyzstan) for logistical support in the field. We thank two anonymous reviewers and S. Sugiyama for their valuable comments. This study is part of the Ili Projects funded by the Research Institute for Humanity and Nature (Japan), and was supported by a Grant-in-Aid for Scientific Research (No. 19253001) from MEXT, Japan.

Edited by: J. O. Hagen

\section{References}

Adler, R. F., Huffman, G. J., Chang, A., Ferraro, R., Xie, P. P., Janowiak, J., Rudolf, B., Schneider, U., Curtis, S., Bolvin, D., Gruber, A., Susskind, J., Arkin, P., and Nelkin, E.: The version-2 global precipitation climatology project (GPCP) monthly precipitation analysis (1979-present), J. Hydrometeorol., 4(6), 11471167, 2003.

Aizen, V. B.: The mass budget of the Golubina Glacier during 1959/60-1981/1982, MGI, 53, 44-45, 1985 (in Russian).

Aizen, V. B., Maximov, N. V., and Solodkov, P. A.: The dynamics of the Goloubin Glacier during the last 20 years, Works SANII, 91(172), 82-87, 1983 (in Russian).

Aizen, V. B., Kuzmichenok, V. A., Surazakov, A. B., and Aizen, E. M.: Glacier changes in the central and northern Tien Shan during the last 140 years based on surface and remote-sensing data, Ann. Glaciol., 43, 202-213, doi:10.3189/172756406781812465, 2006.

Aizen, V. B., Aizen, E. M., and Kuzmichenok, V. A.: Glaciers and hydrological changes in the Tien Shan: simulation and prediction, Environ. Res. Lett., 2, 045019, doi:10.1088/17489326/2/4/045019, 2007a.

Aizen, V. B., Kuzmichenok, V. A., Surazakov, A. B., and Aizen, E. M.: Glacier changes in the Tien Shan as determined from topographic and remotely sensed data, Global Planet. Change, 56, 328-340, doi:10.1016/j.gloplacha.2006.07.016, 2007 b.

ASTER-GDEM: http://www.gdem.aster.ersdac.or.jp, access: 12 March 2011, 2009.

Avsuyk, G. A.: Tuyksu glaciers, Hydrometeo Publishing, Leningrad, USSR, 170 pp., 1984 (in Russian).

Bolch, T.: Climate change and glacier retreat in northern Tien Shan (Kazakhstan/Kyrgyzstan) using remote sensing data, Global Planet. Change, 56(1-2), 1-12, doi:10.1016/j.gloplacha.2006.07.009, 2007.

Dyurgerov, M. B.: Glacier mass balance and regime: data of measurements and analysis, Occasional Paper No. 55, Boulder, Colorado, available at: http://instaar.colorado.edu/other/occ_papers. html, access: 12 March 2011, 2002.

Fujita, K.: Effect of dust event timing on glacier runoff: sensitivity analysis for a Tibetan glacier, Hydrol. Process., 21(21), 28922896, doi:10.1002/hyp.6504, 2007. 
Fujita, K.: Effect of precipitation seasonality on climatic sensitivity of glacier mass balance, Earth Planet. Sci. Lett., 276(1-2), 1419, doi:10.1016/j.eps1.2008.08.028, 2008.

Fujita, K. and Ageta, Y.: Effect of summer accumulation on glacier mass balance on the Tibetan Plateau revealed by mass-balance model, J. Glaciol., 46(153), 244-252, doi:10.3189/172756500781832945, 2000.

Fujita, K., Seko, K., Ageta, Y., Pu, J. C., and Yao, T. D.: Superimposed ice in glacier mass balance on the Tibetan Plateau, J. Glaciol., 42(142), 454-460, 1996.

Fujita, K., Ohta, T., and Ageta, Y.: Characteristics and climatic sensitivities of runoff from a cold-type glacier on the Tibetan Plateau, Hydrol. Process., 21(21), 2882-2891, doi:10.1002/hyp.6505, 2007.

Fujita, K., Suzuki, R., Nuimura, T., and Sakai, A.: Performance of ASTER and SRTM DEMs, and their potential for assessing glacial lakes in the Lunana region, Bhutan Himalaya, J. Glaciol., 54(185), 220-228, doi:10.3189/002214308784886162, 2008.

Fujita, K., Sakai, A., Nuimura, T., Yamaguchi, S., and Sharma, R. R.: Recent changes in Imja Glacial Lake and its damming moraine in the Nepal Himalaya revealed by in-situ surveys and multi-temporal ASTER imagery, Environ. Res. Lett., 4, 045205, doi:10.1088/1748-9326/4/4/045205, 2009.

Golubev, G. N.: The Glacier Hydrology, L. Hydrometeoizdat, 246 pp., 1976 (in Russian).

Glazirin, G. E.: Mountain glacial systems, their structure and evolution, Hydrometeo Publishing, Leningrad, USSR, 110 pp., 1991 (in Russian).

Hagg, W. J., Braun, L. N., Uvarov, V. N., and Makarevich, K. G.: A comparison of three methods of mass balance determination in the Tuyuksu Glacier Region, Tien Shan, J. Glaciol., 50(171), 505-510, doi:10.3189/172756504781829783, 2005.

Hagg, W. J., Braun, L. N., Kuhn, M., and Nesgaard, T. I.: Modelling of hydrological response to climate change in glacierized Central Asian catchments, J. Hydrol., 332(1-2), 40-53, doi:10.1016/j.jhydrol.2006.06.021, 2007.

Jarvis, A., Reuter, H. I., Nelson, A., and Guevara, E.: Hole-filled seamless SRTM data V4, International Centre for Tropical Agriculture (CIAT), available at: http://srtm.csi.cgiar.org/, access: 12 March 2011, 2008.

Kalnay, E., Kanamitsu, M., Kistler, R., Collins, W., Deaven, D., Gandin, L., Iredell, M., Saha, S., White, G., Woollen, J., Zhu, Y., Chelliah, M., Ebisuzaki, W., Higgins, W., Janowiak, J., Mo, K. C., Ropelewski, C., Wang, J., Leetmaa, A., Reynolds, R., Jenne, R., and Joseph, D.: The NCEP/NCAR 40-year reanalysis project, B. Am. Meteorol. Soc., 77(3), 437-471, 1996.

Khromova, T. E., Dyurgerov, M. B., and Barry, R. G.: Late-twentieth century changes in glacier extent in the Ak-shirak Range, Central Asia, determined from historical data and ASTER imagery, Geophys. Res. Lett., 30, 1863, doi:10.1029/2003GL017233, 2003.
Konovalov, V. G.: Computation and Forecast of glacier melt in Central Asia, Hydrometeo Publishing, Leningrad, USSR, 230 pp., 1979 (in Russian).

Krenke, A. N.: Mass exchange in glacial systems on the USSR territory, Hydrometeo Publishing, Leningrad, USSR, 287 pp., 1982 (in Russian).

Kutuzov, S. and Shahgedanova, M.: Glacier retreat and climatic variability in the eastern Terskey-Alatoo, inner Tien Shan between the middle of the 19th century and beginning of the 21st century, Global Planet. Change, 69, 59-70, doi:10.1016/j.gloplacha.2009.07.001, 2009.

Lemke, P., Ren, J., Alley, R. B., Allison, I., Carrasco, J., Flato, G., Fujii, Y., Kaser, G., Mote, P., Thomas, R. H., and Zhang, T.: Observations: changes in snow, ice and frozen ground, in: Climate change 2007: the physical science basis. Contribution of Working Group I to the Fourth Assessment Report of the Intergovernmental Panel on Climate Change, edited by: Solomon, S., Qin, D., Manning, M., Chen, Z., Marquis, M., Averyt, K. B., Tignor, M., and Miller, H. L., Cambridge, etc., Cambridge University Press, 338-383, 2007.

Nagornov, O., Konovalov, Y., and Mikhalenko, V.: Prediction of thermodynamic state of the Gregoriev ice cap, Tien Shan, central Asia, in the future, Ann. Glaciol., 43, 307-312, doi:10.3189/172756406781812221, 2006.

Narama, C., Shimamura, Y., Nakayama, D., and Abdrakhmatov, K.: Recent changes of glacier coverage in the western TerskeyAlatoo range, Kyrgyz Republic, using Corona and Landsat, Ann. Glaciol., 43, 223-229, doi:10.3189/172756406781812195, 2006.

Oerlemans, J. and Fortuin, J. P. F.: Sensitivity of glaciers and small ice caps to greenhouse warming, Science, 258, 115-117, 1992.

Surazakov, A. B. and Aizen, V. B.: Estimating volume change of mountain glaciers using SRTM and map-based topographic data, IEEE T. Geosci. Remote, 44(10), 2991-2995, 2006.

Surazakov, A. B. and Aizen, V. B.: Positional accuracy evaluation of declassified Hexagon KH-9 mapping camera imagery, Photogramm. Eng. Rem. S., 76(5), 603-608, 2010.

Suslov, V. F.: Abramov glacier, Hydrometeo Publishing, Leningrad, USSR, 206 pp., 1980 (in Russian).

Thompson, L. G., Mosley-Thompson, E., Davis, M., Lin, P. N., Yao, T., Dyurgerov, M., and Dai, J.: "Recent warming": ice core evidence from tropical ice cores with emphasis on Central Asia, Global Planet. Change, 7(1-3), 145-156, doi:10.1016/09218181(93)90046-Q, 1993. 